Francis Galton Laboratory for National Eugenies at University College, London, the Royal MedicoPsychological Association, the Central Association for Mental Welfare, and for other representative individuals specially selected for their scientific or medical attainments. In accordance with the terms of the bequest, Prof. R. J. A. Berry will act as chairman of the committee, which will meet in London at the house of the British Medical Association, with Dr. G. C. Anderson as its honorary secretary. As the committee has not yet met, nothing has been determined as to the nature of the researches to be carried out, though doubtless one line of approach will be the hereditary transmission, or otherwise, of mental deficiency and other disorders. Applications will shortly be invited for a specially selected team of investigators, particulars of which will be made known later.

\section{Preliminary Tests for Everest Flight}

A Westland $P V-3$ type two-seater biplane, named the Houston-Westland, fitted with a Bristol Pegasus S.III engine, piloted by Mr. H. J. Penrose, test, pilot at the Westland Aircraft Works, reached a height of $35,000 \mathrm{ft}$. at Yeovil on Wednesday, January 25. The total time in the air was about $1 \mathrm{hr} .40 \mathrm{~min}$. This constitutes a world's record for a two-seater aircraft. This machine has been specially adapted to undertake a flight over Mount Everest in conjunction with an expedition led by AirCommodore P. F. M. Fellowes, with Lord Clydesdale as pilot. Specially designed electrical heating apparatus includes not only heated clothing, but also warming devices for the cabin, the valves of the oxygen apparatus for breathing, many of the instruments and jackets for the cameras. The pilot's cockpit is a normal open one, but is fitted with a hooded windscreen as a protection against draughts. The observer's cockpit is roofed over and is provided with sliding windows in either side and the floor for photographic purposes. Williamson Eagle cameras and cinematograph apparatus are to be used. The machine weighs about $5,000 \mathrm{lb}$. fully loaded as for the Everest flight, and, as is usual with supercharged engines, carries a propeller that allows the full horse power to be developed only after passing $13,000 \mathrm{ft}$. height. Temperatures down to $-40^{\circ} \mathrm{C}$. were registered inside the observer's cabin at the extreme altitude reached. The elimination of vibration, to assist the photography, has been specially dealt with, and in this respect the flight was very successful. A second machine is being converted similarly to take part in the expedition.

\section{Aircraft in Relation to Petroleum Technology}

THIs subject has recently received a good deal of technical and non-technical publicity, both in Great Britain and abroad. Resulting from the extensive use of aeroplanes during the War for reconnaissance and survey purposes, aircraft operations afterwards gained a firm foothold in the technique of exploration, particularly in inaccessible territory. Developments were rapid and the applications to map-making were perfected and commercialised. The incidence of aircraft as an important factor in geological studies is of more recent date and primarily owes its recognition to the important work carried out in North and South America in connexion with exploration for petroleum, including the survey of pipe-line tracks. Both in the realm of petroleum technology and mining geology, aerial reconnaissance and photography have proved valuable as time- and moneysaving factors. The literature on this aspect of the subject has grown extensively during the last few years, and probably one of the most complete accounts of the subject was given by Mr. Donald Gill before the Institution of Mining and Metallurgy recently, when he dealt with "Aerial Survey in Relation to Economic Geology". This paper contains a useful bibliography, which has been reproduced with additions by Mr. H. Hemming, who discussed the commercial aspects of the subject at a meeting of the Institution of Petroleum Technologists on January 10. Mr. Hemming showed clearly that the main value attached to the use of aircraft in exploratory work is for obtaining rapidly information of technical value, and for transporting personnel or material from one place to another. He gave a very succinct account, not only of what has already been accomplished in this direction, but also of the potentialities of further development of air survey.

\section{Empire Broadcasting}

SrNCE the opening of the Empire Broadcasting Station at Daventry on December 19 (see NATURE, 131, 16, Jan. 7, 1933) the British Broadcasting Corporation has received a large number of cable. grams reporting reception of the transmissions in all parts of the world. A very large number of letters has also been received from listeners, and extracts from some of these are published in recent issues of World Radio, which is now the official organ of Empire broadcasting. Good quality reception is reported from such places as Bagdad, the Federated Malay States, Zululand, Tanganyika, various parts of India, New Zealand, and North and South America. In some places, particularly South Africa, local atmospheric conditions have marred the reception to some extent, but on the whole it would appear from the first few weeks' tests that the inauguration of the new Empire broadcasting service has been a conspicuous success. The aerial arrays and the transmitters for the Empire Broadcasting Station at Daventry were designed, constructed and installed by Messrs. Standard Telephones and Cables Ltd.

\section{Anthropological Survey of Ireland}

A FIVE-YEAR plan for an anthropological survey of Ireland has been formulated by anthropological members of Harvard University. It will cover the archæology, social anthropology and the physical characters of the Irish people. In a preliminary account and progress report of the survey (Science, vol. 76, No. 1978) its object is said to be "to produce some sort of scientific interpretation of the Irish 
people". The proposal has been cordially received in Ireland, and now has the official approval of the President of the Irish Free State. The archæological section of the expedition is already at work and during the past summer, under the leadership of Dr. O'Neil Hencken and under the auspices of the National Museum of Ireland, has been engaged in the excavation of a Viking age crannog at Ballinderry, Co. Westmeath, and of bronze age burials nearby at Knockast, with remarkable results. For the study of social anthropology, Co. Clare has been chosen as the area affording most typically a blend of the old and the new in Irish culture. A preliminary survey has been made by Prof. W. Lloyd Warner, assistant professor of social anthropology in Harvard University, assisted by $\mathrm{Mr}$. Conrad Arensburg, postgraduate anthropological student of the University. It is intended to devote two years with an extended staff to the observation of every aspect of Irish social life. Physical anthropology will be under the charge of Prof. E. A. Hooton, of Harvard University, who will also be responsible for the general oversight of the work of the expedition.

\section{Excavation in Alaska}

Durrng the past summer an expedition of the University Museum of Pennsylvania, conducted by Miss Frederika de Laguna, has been at work on the coasts of Alaska in conformity with the policy of American anthropology for the intensive study of this area in relation to the problem of the early peopling of America. The expedition was engaged in the excavation of a prehistoric village site in Kachemak Bay, Cook Inlet. Of the finds of the season, Science Service (Washington D.C.) reports that Miss de Laguna regards the outstanding object to be a carved stone lamp. In the bowl of the lamp is a human figure in an attitude of prayer carved in full relief. Four other examples of such lamps are known; but this is the only example to be found by a scientific explorer in situ. It is said to come from the last phase of four prehistoric Eskimo settlements; but although the early phase of the 'archaic' culture of the area is remarkable for its carved ivories, stone carving is not known as an Eskimo technique. The lamp was found in a shell-heap close to the sea, which is washed by high tide. Other cultural features of the same settlement were slate mirrors, slate blades for lances, bone harpoons and dart heads, grinding stones, awls, drills, dolls, beads and needles. Rock-paintings were found in caves. Such paintings are known only in southern Cook Inlet and on Kodiak Island, where the culture is similar. The Indians of to-day believe that these pictures were painted by 'whale killers', much feared medicinemen who poisoned their lances with human fat. If there were any foundation for this belief, it might be related to the traces of cannibalism found in prehistoric settlements by the Smithsonian Alaskan expeditions.

\section{Spelling of Place Names}

THe United States Geographic Board has published a "First Report on Foreign Geographical
Names" (Washington Government Printing Office, 1932. 10 cents). The list of names is prefaced by a long discussion of the problems involved, which is followed by certain general rules that the Board has adopted. The conventional English usage is adopted for the names of countries, dominions, colonies, etc., and for geographical features common to several States in which the official languages are different. For local geographical names in States where a Latin alphabet is used, the names are spelled in accordance with local usage but conventional English forms, where such exist, are accepted as alternatives. Names in non-Latin alphabets are to be transliterated according to either official transliteration, where such exists, or a system adopted by the Board and printed in this report. The practice of translating names is discouraged. The policy adopted by the Board differs little from that used by the Permanent Committee on Geographical Names for British Official Use. The differences lie in the spelling of names in possessions of European powers and in the transliteration of ' $\mathrm{j}$ ' and ' $\mathrm{zh}$ ' in certain languages, but it is laid down that in the absence of any specific decision of the United States Board, the decision of the British Committee is to be followed in certain cases. The actual list of names in the Report gives pronunciation in many cases but omits it in several names where its addition would certainly be useful.

\section{Forest Fires in Japan}

A PAPER on "Forest Fires and Weather" (Sci. Papers Inst. Phys. Chem. Res., Tokyo, vol. 18), by T. Terada and T. Utigasaki, states that the annual loss due to forest fires in Japan is second in magnitude only to that suffered by the United. States. Japanese meteorologists might therefore do good service by studying the weather conditions that precede these fires in Japan, and perhaps eventually organising a system of warnings, following the example of the United States. The authors of this paper were led to study this subject with the aid of synoptic weather charts through the known tendency for the fires to break out practically simultaneously in widely scattered parts of Japan. They conclude that such outbreaks are generally associated with the near approach of the 'squall-line' or principal cold front of a depression following an easterly track north of Japan, when the warmer of the two wind currents yields maximum temperatures of $20^{\circ} \mathrm{C}$. or more. There seems no a priori reason why the front should have anything to do with the matter ; it is easy to imagine that the necessary antecedent conditions are merely a sufficiency of wind and warmth, with no rain and perhaps some special state of the air in regard to its water-vapour content. These conditions might seldom occur except on the approach of a depression. As frequently happens with investigations in which synoptic charts are used, the extent to which the evidence supports the conclusions cannot be gauged accurately unless all the charts are reproduced in great detail. It must have been difficult for the authors to determine the position of the front in 